\title{
High incidence of chromosomal abnormalities at 1p36 and 9p21 in early-stage central type squamous cell carcinoma and squamous dysplasia of bronchus detected by autofluorescence bronchoscopy
}

\author{
KIYOKO SHIBUKAWA ${ }^{1}$, NAOYUKI MIYOKAWA ${ }^{2}$, YOSHIHIKO TOKUSASHI ${ }^{2}$, \\ TAKAAKI SASAKI ${ }^{1}$, SHINOBU OSANAI ${ }^{1}$ and YOSHINOBU OHSAKI ${ }^{1}$ \\ ${ }^{1}$ Respiratory Center and ${ }^{2}$ Department of Surgical Pathology, Asahikawa Medical College, \\ 2-1-1-1 Midorigaoka Higashi, Asahikawa 078-8510, Japan
}

Received February 25, 2009; Accepted March 30, 2009

DOI: $10.3892 /$ or_00000409

\begin{abstract}
Heavy smokers with central type squamous cell carcinoma (SCC) frequently have multiple cancerous lesions in the bronchus. Autofluorescence bronchoscopy (AFB) is useful in the detection of early bronchogenic cancer and dysplastic lesions. We investigated the loss of heterozygosity (LOH) and microsatellite instability (MSI) and expression of four proteins in 13 early stage SCC (early SCC) and 9 squamous dysplasia detected by $\mathrm{AFB}$ and 19 cases of surgically resected invasive SCC (invasive SCC). In early SCC and squamous dysplasia, LOH/MSI of chromosome $1 \mathrm{p} 36$ was found in 62 and 33\%, respectively, and of 9p21 in 54 and $63 \%$, respectively. TAp73 expression of early SCC and squamous dysplasia was lower than that of normal bronchial epithelium, and p16 expression was not detectable in these lesions. These results suggested that the genetic abnormalities had already developed in the early stage of carcinogenesis of SCC, including squamous dysplasia. The AFB system was able to reveal abnormal autofluorescence in these precancerous lesions, including squamous dysplasia.
\end{abstract}

\section{Introduction}

Lung cancer is the leading cause of cancer death in the industrialized countries including Japan (1). Detection of lung cancers in their early stages is the most significant way to improve the clinical course of the disease. The 5-year

Correspondence to: Dr Yoshinobu Ohsaki, Respiratory Center, Asahikawa Medical College, 2-1-1-1 Midorigaoka Higashi, Asahikawa 078-8510, Japan

E-mail: yohsaki@asahikawa-med.ac.jp

Key words: autofluorescence bronchoscopy, squamous cell carcinoma, squamous dysplasia, $p 73, p 16$, loss of heterozygosity, microsatellite instability survival rates of non-small cell lung carcinoma (NSCLC) are $44-79.5 \%$ for stage I, $29-59.9 \%$ for stage II, 6-19.3\% for stage III and $2-20 \%$ for stage IV $(2,3)$. Squamous cell carcinoma (SCC) accounts for almost $30 \%$ of all lung cancers (4), and tobacco smoking is associated with an increased risk for bronchogenic SCC (5). Heavy smokers with central type SCC frequently have multiple cancerous lesions in the bronchus. In Japanese, the relative risk of lung cancer for current smokers versus never smokers was estimated to be 4.39 for men and 2.79 for women, especially, the relative risks for SCC were as high as 11.7 and 11.3, respectively (6). Early-stage central type lung cancers are curable with even a low-invasive endobronchial treatment such as a photodynamic therapy (PDT) (7-9) when the cancers are limited to the mucosa, i.e., carcinoma in situ (CIS).

Nearly $90 \%$ of pulmonary SCC is located at the central bronchus (10). Examinations to detect central type lung cancers include sputum cytological examination and bronchoscopic examination, and these procedures are well established in terms of screening bronchogenic SCC (11). However, it is often difficult to detect early stage SCC or dysplastic lesions by only white-light bronchoscopy (WLB).

It is reported that autofluorescence bronchoscopy (AFB) systems are useful to detect dysplastic lesions and bronchogenic cancers in situ in the early stages (12-16). Lam et al examined 173 subjects known or suspected to have lung cancer using the light-induced fluorescence endoscopy (LIFE) device (Xillix Technologies Corp., Richmond, BC, Canada) $(14,17)$. They reported that the relative sensitivity of WLB+LIFE vs. WLB alone was 6.3 for intraepithelial neoplastic lesions and that the LIFE system improved the ability to detect dysplastic malignant lesions (14). Chiyo et al compared the autofluorescence imaging bronchovideoscope (AFI) system (Olympus Optical Corp., Tokyo, Japan) with the LIFE system in 32 patients with suspected cancer, malignant sputum cytology, and known lung cancer (18). The sensitivities of dysplasia detection by LIFE and AFI were 96.7 and $80 \%$, respectively, and the specificities were 36.6 and $83.3 \%$, respectively. Thus, the specificity of AFI was significantly better $(\mathrm{p}<0.01)$. Nakanishi et al reported using a color 
fluorescence endoscopic system, PDS-2000 (Hamamatsu Photonics K.K., Hamamatsu, Japan) $(19,20)$ that enabled observation of the color autofluorescence from the bronchial wall, and that addition of AFB significantly improved detection of early central lung cancers and dysplastic lesions in comparison with only WLB (21). Therefore, observation of autofluorescence from the bronchial wall seems to improve detection of early bronchogenic cancer.

Human cancers are now widely accepted to be genetic diseases developing through the accumulation of genetic alterations in critical genes. It is reported that human cancers are caused by activation of oncogenes such as $K$-ras, $c-m y c$, and $b c l-2$, and/or inactivation of tumor suppressor genes such as $p 53, P T E N$ and $A P C$ (22-25). Measurement of loss of heterozygosity $(\mathrm{LOH})$ or microsatellite instability (MSI) is a method of chromosomal analysis using microsatellite markers. Many studies of LOH/MSI in various cancers have been performed. LOH has been used as an indicator for the targeted deletion of tumor suppressor genes such as FHIT gene at 3 p14, p53 gene at 17p13, and CDKN2 gene at 9p21 (26-29). Pan et al studied surgically resected specimens and reported that $\mathrm{LOH}$ of $1 \mathrm{p}, 3 \mathrm{p}, 5 \mathrm{q}, 17 \mathrm{p}$ and $18 \mathrm{q}$ were common in the tobacco smoking-related NSCLC (30). Yoshino et al reported that the incidence of $\mathrm{LOH}$ in SCC of the lung was higher than that in adenocarcinoma (31).

To clarify the efficacy of autofluorescence bronchoscopy in the detection of early lung bronchogenic cancer, especially in terms of genetic abnormalities, we analyzed the chromosomal abnormalities and protein expressions in early-stage central type SCC and precancerous lesions that were found by AFB using a polymerase chain reaction (PCR)-LOH/MSI method. Further, we studied the differences of LOH/MSI, protein expression, and pathological findings between early bronchogenic cancers and invasive bronchogenic cancers to reveal the significant genetic alterations in early and advanced bronchogenic cancer.

\section{Materials and methods}

\section{Patients and samples}

Early-stage central type squamous cell carcinoma and squamous dysplasia. We diagnosed early-stage central type SCC (early SCC) when the characteristics fulfilled both criteria A and B of the Japan Lung Cancer Society (32). Criteria A (clinical criteria) were normal X-ray examinations of the chest and no lymph node metastases or distant metastases. Criteria B (bronchoscopic criteria) were cancerous lesions located from the trachea to the subsegmental bronchus, the distal margin of cancerous lesions could be visualized by bronchoscopy, the size of cancerous lesions was $<2 \mathrm{~cm}$, cancerous lesions were diagnosed as SCC pathologically, and they were limited to the mucosa.

Fifteen patients with early SCC underwent PDT from 2001-2007 at the Asahikawa Medical College Hospital. Among these 15, 13 patients agreed to participate in this study (Table I). Written informed consent was obtained from the patients before pre-PDT bronchoscopy. The study was approved by the ethics committee of the Asahikawa Medical College. All patients were male, and their pack-year indices were $>50$.
Table I. Clinicopathological characteristics.

\begin{tabular}{lcc}
\hline Patients & $\begin{array}{c}\text { Early SCC } \\
(\mathrm{n}=13)\end{array}$ & $\begin{array}{c}\text { Invasive SCC } \\
(\mathrm{n}=19)\end{array}$ \\
\hline Age (average \pm SD $)$ & $72.5 \pm 6$ & $67.0 \pm 9$ \\
Gender & & \\
Male & 13 & 18 \\
Female & 0 & 1 \\
Pack-year index & & \\
Never & 0 & 2 \\
$<50$ & 3 & 8 \\
$50-75$ & 4 & 3 \\
$\geq 75$ & 6 & 6 \\
\hline
\end{tabular}

Early SCC lesions and moderate-to-severe dysplastic lesions of the bronchus were collected by biopsy from bronchial lesions that emitted abnormal color fluorescence during examination using the AFB system, PDS-2000. We classified moderate-to-severe dysplastic lesions as squamous dysplasia in the present study. Pathological diagnosis of each lesion was confirmed microscopically by two pathologists according to the World Health Organization criteria. Thirteen early SCC and nine squamous dysplasia were obtained from the 13 cases. These squamous dysplasia were localized to the lober bronchus or segmental bronchus. Normal bronchial epithelia were also obtained by the bronchial biopsy.

Invasive squamous cell carcinoma. We examined 19 cases of SCC of the lung with interstitial tissue invasion that had been surgically resected in 2004 and 2005 at the Asahikawa Medical College Hospital and that agreed to participate in this study (Table I). The tumors were staged according to the International Union Against Cancer tumor-node-metastasis (TNM) classification system and histologically sub-typed and graded according to the World Health Organization guidelines. Pathological stages of the cancer was 14 stage I, 1 stage II, 3 stage III and 1 stage IV (32).

DNA extraction. We used the laser microdissection and pressure catapulting (LMPC) method (PALM Micro Laser Systems, Germany) to isolate nuclei of cancerous, dysplastic, and normal bronchial epithelial cells from paraffin-embedded tissue specimens. Paraffin-embedded specimens were cut $8 \mu \mathrm{m}$ thick, and 3000 nuclei were collected by LMPC. DNA was extracted from these nuclei using $100 \mu 1$ DNA extraction buffer [50 mM Tris-HCl (pH 8.0), 1 mM EDTA (pH 8.0), $0.5 \%$ Tween-20, and proteinase $\mathrm{K}(1 \mathrm{mg} / \mathrm{ml})]$ incubated at $37^{\circ} \mathrm{C}$ for overnight. After proteinase $\mathrm{K}$ heat denaturing, we used $3 \mu 1$ of this extracted DNA solution ( $\sim 90$ microdissected nuclear DNA) as a PCR template.

Analysis of loss of heterozygosity and microsatellite instability. Analysis of LOH and MSI was performed by the PCR-LOH/ MSI method. We examined two microsatellite loci on 
Table II. Immunohistochemical antibodies.

\begin{tabular}{llll}
\hline Antibody & Clone & Dilution & \multicolumn{1}{c}{ Source } \\
\hline p73 & Ab-4 & $1: 100$ & Calbiochem \\
p16 & 6 H12 & $1: 40$ & Novocastra \\
p53 & DO-7 & $1: 50$ & DakoCytomation \\
Ki-67 & MIB-1 & $1: 100$ & DakoCytomation \\
\hline
\end{tabular}

different chromosomes for LOH/MSI using D1S2672 for 1 p36 and D9S1748 for 9p21. Primer sequences were obtained from the Human Genome Database. p73 localizes to 1p36 and p16 to $9 \mathrm{p} 21$, respectively. Forward primer of each primer pair was fluorescence-labeled by carboxyfluorescein at the 5'-end (Applied Biosystems, Tokyo, Japan).

The PCR was carried out in a final volume of $15 \mu \mathrm{l}$ containing 1.5 $\mu \mathrm{l} 10 \mathrm{X}$ PCR buffer, $1.5 \mu \mathrm{l}$ magnesium chloride (25 mM), $1.5 \mu 1$ of each dNTP (2.5 mM), 0.12 U AmpliTaq Gold polymerase (Applied Biosystems), and $3 \mu 1$ of DNA template. The PCR conditions were starting denaturation at $95^{\circ} \mathrm{C}$ for $12 \mathrm{~min}$, followed by 40 cycles of denaturation at $94^{\circ} \mathrm{C}$ for $15 \mathrm{sec}$, annealing at $55^{\circ} \mathrm{C}$ for $15 \mathrm{sec}$, extension at $72^{\circ} \mathrm{C}$ for $30 \mathrm{sec}$, and final extension at $72^{\circ} \mathrm{C}$ for $10 \mathrm{~min}$. The PCR products were denatured by formamide together with GeneScan 400HD ROX Size Standard (Applied Biosystems). All PCR products were analyzed using an ABI PRISM 310 Genetic Analyzer (Applied Biosystems), based on capillary electrophoresis, and the sizes of the PCR products for the allele were measured by a GeneScan system (Applied Biosystems).

To determine $\mathrm{LOH}$, the height of gel peaks was measured in relative fluorescent units. For each informative case (showing two alleles in normal tissue), the height of the major peak of each allele was considered, being consistent with the highest one. A ratio between normal and carcinoma (or dysplasia) tissue peak was calculated as follows: allele ratio = (peak height of normal allele 2/peak height of normal allele 1)/ (peak height of carcinoma allele 2/peak height of carcinoma allele 1). LOH event was considered when the allele ratio was $<0.5$ or $>2.0(33,34)$.

MSI was defined by existence of additional peaks or displaced peaks, which showed two or more base pair size difference compared with that of the normal bronchial epithelial DNA (35).

Immunohistochemical staining. The antibodies we used in this study were p73 (Calbiochem, Darmstadt, Germany), p16 (Novocastra, Newcastle, UK) and p53 (DakoCytomation, Glostrup, Denmark), and Ki-67 (DakoCytomation) (Table II).

This p53 antibody detected mainly mutated p53. Ki-67 is most often used as a marker for proliferating cells (36). The antibody anti-p73 protein using in this study can detect only transcriptionally active (TA) wild-type p73. Paraffinembedded tissues were sectioned at $4 \mu \mathrm{m}$ thickness and mounted on silicon-coated glass slides. Deparaffinized sections were placed in methanol containing 3\% hydrogen peroxide for $30 \mathrm{~min}$ to block endogenous peroxidase activity, followed by washing three times with $0.01 \mathrm{M}$ phosphate-buffered saline (PBS), pH 7.4, for 5 min each. Microwave treatment was employed as an antigen retrieval method; the sections were

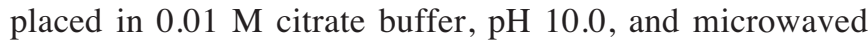
twice at $98^{\circ} \mathrm{C}$ for $10 \mathrm{~min}$. The Envision plus system (DakoCytomation) was used as the immunohistochemical detection procedure in this study. The following steps were performed at $25^{\circ} \mathrm{C}$. After antigen retrieval, the sections were blocked using a non-specific staining blocking solution containing $0.25 \%$ casein (DakoCytomation) for $5 \mathrm{~min}$, and then washed three times with PBS.

Samples were treated with a primary antibody overnight for p73 and p16 staining, and for 30 min for mutated p53 and Ki-67 staining, and then washed three times with PBS. Envision plus was added for each samples and incubated for $30 \mathrm{~min}$. After washing with PBS three times, sections were immersed in hydrogen peroxidase and 3,3'-diaminobenzidine solution for $2 \mathrm{~min}$. After rinsing with purified water three times, all sections were counterstained with Mayer's hematoxylin and mounted with Entellan-new (Merck, Darmstadt, Germany). Specific staining was identified by the presence of brown reaction products. Control sections resected from other patients with ovarian carcinoma for $\mathrm{p} 73$, pancreas carcinoma for $\mathrm{p} 16$, colon carcinoma for mutated $\mathrm{p} 53$, and tonsil for Ki-67 were incubated with or without primary antibodies, as positive and negative controls, respectively.

Immunohistochemical scoring. Immunostained slides were evaluated by light microscopy. Results of immunohistochemical (IHC) staining were classified as: 0 , none; $1,<1 \%$; $2,2-10 \% ; 3,11-33 \% ; 4,34-66 \%$; and $5,>67 \%$, using a proportion scoring method. The intensity of positive staining in nuclei and cytoplasm was classified as: 0 , none; 1 , weak; 2 , intermediate; and 3, strong, using an intensity scoring method. The proportion and intensity scores were combined to obtain a total score ranging from 0 to 8 as the IHC score (Fig. 1) (37). Slides were scored by one pathologist who did not have any knowledge of the history of the patients.

Statistical analysis. For LOH/MSI analysis, statistical comparisons were performed by using a $2 \times 2 \chi^{2}$ test. For immunohistochemical scoring, statistical comparisons were done by Wilcoxon's signed rank test or Mann-Whitney's U test. The difference was considered statistically significant when the p-value was $<0.05$.

\section{Results}

PCR-LOH/MSI analysis of early SCC and squamous dysplasia of bronchus detected by AFB. Table III shows the results of PCR-LOH/MSI analysis in early SCC and squamous dysplasia of the bronchus detected by AFB. In 13 DNA samples from lesions with early SCC, LOH/MSI was found in $62 \%(8 / 13)$ for chromosome $1 \mathrm{p} 36$ and in $54 \%(7 / 13)$ for $9 \mathrm{p} 21$. In nine DNA samples from lesions of squamous dysplasia of the bronchus, we could not amplify one sample for 9p21. LOH/ MSI was found in 33\% (3/9) and 63\% (5/8), respectively. Thus, chromosomal abnormalities of 1p36 and 9p21 were frequently found in DNA samples from early SCC and squamous dysplasia. 

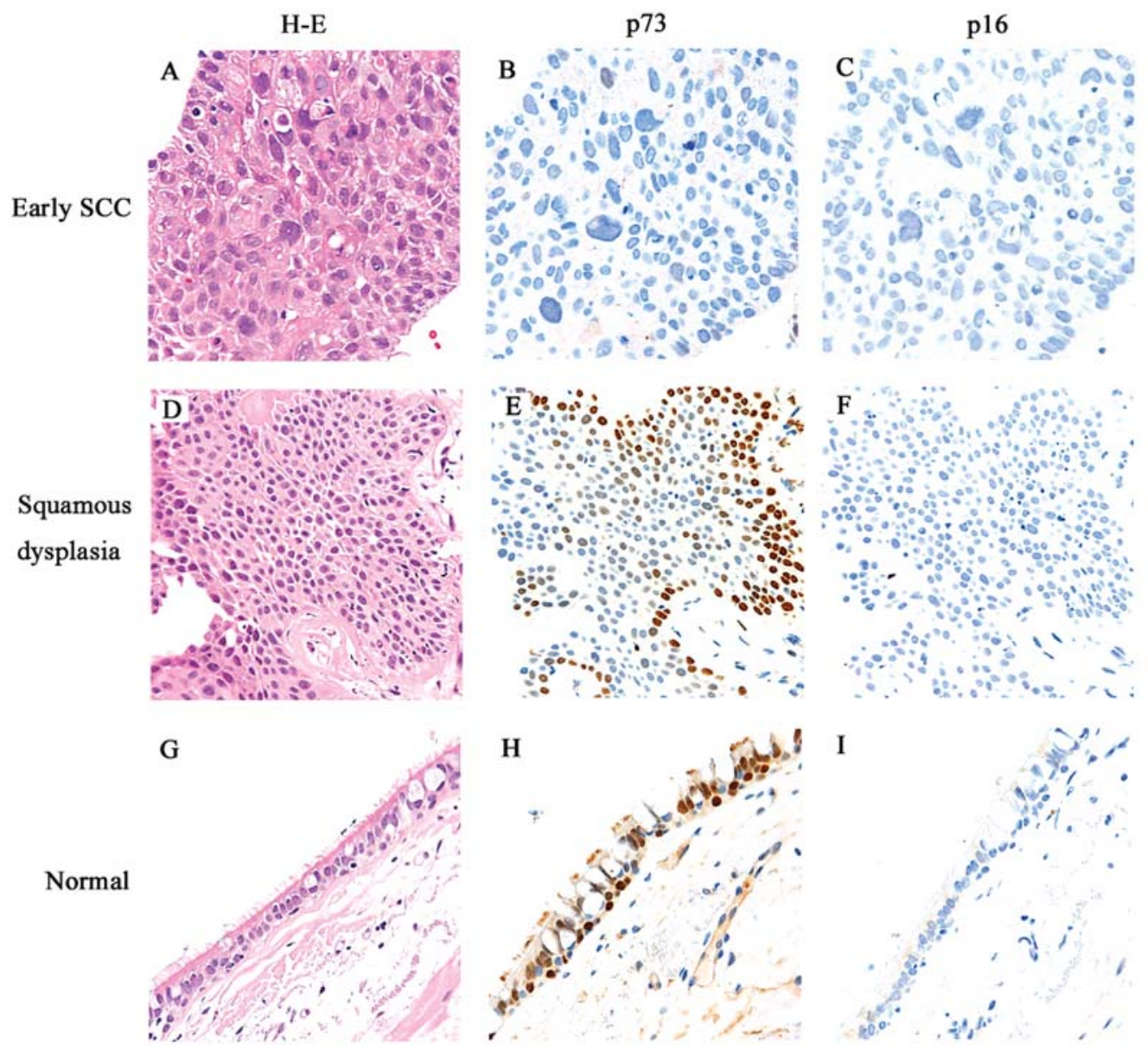

Positive sample of

p16 protein

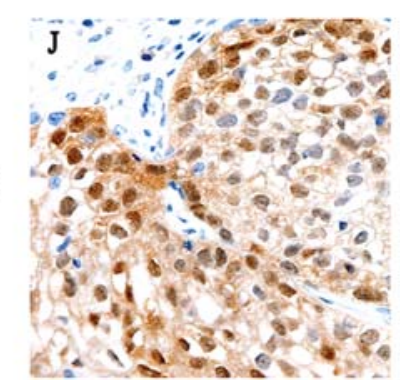

Figure 1. Hematoxylin-eosin (H-E) staining and immunohistochemical (IHC) staining of early SCC, squamous dysplasia and normal bronchial epithelium (x200). (A, D and G) H-E staining of early SCC, squamous dysplasia, and normal bronchial epithelium (Normal). p73 IHC score of early SCC was zero (B), squamous dysplasia was six (proportion score, 3; intensity score, 3) (E), normal bronchial epithelium was eight (proportion score, 5; intensity score, 3 ) (H). (C, F and I) p16 IHC scores of early SCC, squamous dysplasia, and normal bronchial epithelium were zero. (J) Invasive SCC, p16 IHC staining was strongly positive, as a positive control. IHC score was six (proportion score, 3 ; intensity score, 3 ).

Table III. Ratio of chromosomal abnormalities in early SCC, squamous dysplasia, and invasive SCC.

\begin{tabular}{lcccc}
\hline Locus & $\begin{array}{c}\text { Microsatellite } \\
\text { markers }\end{array}$ & $\begin{array}{c}\text { Squamous } \\
\text { dysplasia (\%) }\end{array}$ & $\begin{array}{c}\text { Early } \\
\text { SCC (\%) }\end{array}$ & $\begin{array}{c}\text { Invasive } \\
\text { SCC (\%) }\end{array}$ \\
\hline 1p36 & D1S2672 & $33(3 / 9)$ & $62(8 / 13)$ & $44(7 / 16)$ \\
9p21 & D9S1748 & $63(5 / 8)$ & $54(7 / 13)$ & $84(16 / 19)$ \\
\hline
\end{tabular}

Immunohistochemical scoring of early SCC and squamous dysplasia of bronchus detected by AFB. Table IV shows the IHC scores of p73, p16, mutated p53 and Ki-67 proteins in lesions with early SCC or squamous dysplasia of the bronchus.
IHC scores for Ki-67 and mutated p53 protein in early SCC and squamous dysplasia were significantly higher than those in the normal bronchial epithelium. In contrast, the IHC score for p73 protein in early SCC and squamous dysplasia was significantly lower than those in the normal bronchial epithelium. There was no significant difference in IHC scores for p16 protein between early SCC or squamous dysplasia and normal bronchial epithelium. When the IHC scores of all early SCC and squamous dysplasia of the bronchus were compared, no statistically significant differences were found.

PCR-LOH/MSI analysis of invasive SCC. Table III shows the results of PCR-LOH/MSI analysis of invasive SCC. In 19 DNA samples from invasive SCC tissues, we were not able 
Table IV. IHC scores of early SCC, squamous dysplasia and normal bronchial epithelium.

\begin{tabular}{|c|c|c|c|c|c|c|c|}
\hline & p73 & p16 & p53 & & Ki-67 & & \\
\hline Normal $^{\mathrm{a}}$ & $7.3 \pm 0.6^{\mathrm{c}}$ & $0.3 \pm 0.8$ & $0.4 \pm 0.6-$ & & $1.1 \pm 1.1$ & t & \\
\hline Dysplasia $^{\mathrm{b}}$ & $5.0 \pm 1.2$ & $0.9 \pm 1.2$ & $2.9 \pm 2.4-$ & * & $4.5 \pm 2.0$ & & * \\
\hline Early SCC & $5.2 \pm 1.9$ & $0.9 \pm 1.8$ & $4.3 \pm 3.2$ & & $5.6 \pm 1.9$ & & \\
\hline
\end{tabular}

${ }^{a}$ Normal bronchial epithelium; ${ }^{b}$ squamous dysplasia; ${ }^{c}$ average \pm SD. ${ }^{*}$ Considered to be significant $(\mathrm{p}<0.01)$. ${ }^{* *}$ Considered to be significant $(\mathrm{p}<0.05)$.

Table V. IHC scores of invasive SCC and normal bronchial epithelium.

\begin{tabular}{|c|c|c|c|c|}
\hline & p73 & p16 & p53 & $\mathrm{Ki}-67$ \\
\hline Normal $^{\mathrm{a}}$ & $6.4 \pm 0.8^{\mathrm{b}}$ & 0 & $0 \quad-$ & $0.6 \pm 0.9-$ \\
\hline Invasive SCC & $4.4 \pm 2.0$ & $0.8 \pm 2.0$ & $5.1 \pm 3.2$ & $6.4 \pm 1.1$ \\
\hline
\end{tabular}

${ }^{a}$ Normal bronchial epithelium; ${ }^{b}$ average \pm SD. ${ }^{*}$ Considered to be significant $(\mathrm{p}<0.01)$.

Table VI. IHC scores compared with early SCC and invasive SCC.

\begin{tabular}{lc} 
Protein & $\begin{array}{c}\text { Early SCC vs. invasive SCC } \\
\text { p-value }\end{array}$ \\
\hline p73 & 0.1816 \\
p16 & 0.6382 \\
p53 & 0.2696 \\
Ki-67 & 0.3237 \\
\hline
\end{tabular}

${ }^{\mathrm{a} C}$ Comparison between early SCC and invasive SCC.

to amplify three samples for $1 \mathrm{p} 36$. LOH/MSI was detected in $44 \%(7 / 16)$ for $1 \mathrm{p} 36$ and in $84 \%(16 / 19)$ for $9 \mathrm{p} 21$.

Immunohistochemical scoring of invasive SCC. Table V shows a summary of IHC scores in invasive SCC. Ki-67 and mutated p53 IHC scores of invasive SCC were significantly higher than those of normal bronchial epithelium. p73 IHC score of invasive SCC was significantly lower than that of normal bronchial epithelium. There was no significant difference in IHC scores for p16 protein between invasive SCC and normal bronchial epithelium.

Comparison of PCR-LOH/MSI analysis and immunohistochemical scores in early and invasive SCC. In the PCR$\mathrm{LOH} / \mathrm{MSI}$ analysis, the frequencies of LOH/MSI in 1p36 and 9p21 in early SCC and invasive SCC were not statistically different (Table III). No statistically significant differences were found between IHC scores of p73, p16, mutated p53, and Ki-67 of early SCC and invasive SCC (Table VI).

\section{Discussion}

In this study we revealed that autofluorescence observed on AFB reflected genetic abnormalities in the bronchial epithelium. We investigated the abnormalities of two chromosomal regions and the expression levels of the tumor suppressor gene products in the AFB detectable early bronchogenic lesions. Further, we investigated whether there was a difference in chromosomal abnormalities and protein expression between early and late stages of SCC carcinogenesis by compared with early SCC and invasive SCC. We used the LMPC method because it enabled LOH/MSI analysis of very small pathological samples such as biopsy specimens from the bronchial wall obtained by bronchoscopy. The nuclear DNA examined from SCC, squamous dysplasia, and normal bronchial epithelial cells was confirmed by microscopy. Therefore, the results of LOH/MSI of these lesions could be accurately compared in the present study.

We selected two chromosomal regions, 1p36 and 9p21 in the LOH/MSI analysis. The tumor suppressor genes associated with these sites are $p 73$ and $p 16$, respectively $(38,39) . p 73$ was identified as a p53 family member that showed substantial structural and functional homology with p53 (40) and has many p53-like properties; i.e., it binds p53 DNA target sites, transactivates p53-responsive genes, and induces cell cycle arrest or apoptosis by promoting cell cycle progression in the 
G1/S phase $(41,42)$. p16 is a member of the inhibitors of cyclin-dependent kinases 4 (INK4) family. Other members such as p15, p18 and p19 are structurally related to p16 (43). These proteins inhibit cyclin-dependent kinase (Cdk) 4 and Cdk6 in the G1 phase.

p73 is expressed as transcriptionally active (TA) and transcriptionally inactive $(\Delta \mathrm{N})$ forms $(38,42,44,45)$. TAp73 has a pro-apoptotic activity similar to wild-type p53 $(41,42)$. In contrast, $\triangle \mathrm{Np} 73$ displays dominant negative behavior against TAp73 and wild-type p53 (46). This protein has been reported to have oncogenic potential (47). The balance between intracellular expression levels of pro-apoptotic TAp73 or p53 and anti-apoptotic $\Delta \mathrm{Np} 73$ seems to be important in the regulation of cell cycle progression (42). The anti-p73 antibody used in the present study detects only the wild-type TAp73 protein, which plays an important role as a tumor suppressor (38), as described above. Nomoto et al reported frequent allelic loss at the $p 73$ locus at 1p36 in NSCLC, especially in SCC (48).

p16 plays an important role in the arrest of proliferation of cells at senescence (43). $\mathrm{LOH}$ at 9p21, absence of p16 expression, and methylation of p16 have been reported in various cancer cell lines. Sharpless et al reported that $p 16$ knockout mice were prone to develop tumors and indicated that this protein has a role as a tumor suppressor (49). Kishimoto et al proposed that $\mathrm{LOH}$ at the 9p locus occurred at the earliest stage in the pathogenesis of lung cancer (50). Tissues without p16 expression have been found more frequently in SCC than in adenocarcinoma (51-53).

In the present study, early SCC and squamous dysplasia that emitted abnormal autofluorescence colors had high incidence of chromosomal abnormalities in 1p36 and 9p21 on PCR-LOH/MSI analysis. These results suggested that these chromosomal abnormalities had already developed in the early stages of carcinogenesis of SCC including squamous dysplasia of the bronchus. Expression levels of TAp73 protein in early SCC and squamous dysplasia were significantly lower than that in normal bronchial epithelium. This reduction of TAp73 expression might be related to LOH or MSI of 1p36. Interestingly, our study revealed overexpression of TAp73 protein in the normal bronchial epithelium. It was reported that the expression levels of TAp73 protein are maintained at a low level under normal physiological conditions (42). The majority of normal bronchial epithelium used in this study was obtained from smokers. On the other hand, we examined the expression levels of TAp73 using normal bronchial epithelium obtained from four non-smokers, and found that expression levels of TAp73 in non-smokers were similar to those in smokers. Furthermore, the other normal epithelium from different organs did not express TAp73 detected by IHC staining (data not shown). Our result revealed that DNA repair through the TAp73 pathway had already occurred in the normal bronchial epithelium independent of smoking. The bronchial epithelium could be continuously exposed to a small amount of toxic substances in the air. Therefore, the increased TAp73 expression in our study potentially reflected initiation of bronchial wall damage by toxic substances. Toxic substances in tobacco tar might play a role in the damage on some genes independent of p73 pathway, or as the second hit on bronchogenic carcinogenesis.
Expression of p16 protein was less frequent in early SCC and squamous dysplasia, although Ki-67 expression increased in these tissues. The decrease of p16 expression was considered to relate to $\mathrm{LOH}$ or MSI of $9 \mathrm{p} 21$. These results suggested that LOH/MSI of 9p21 causes a loss of p16 expression, and finally carcinogenesis in SCC (50). Further, the expression of mutated p53 was high not only in early and invasive SCC but also in squamous dysplasia. These results confirmed previous observations of a significant association between $p 53$ mutations and $\mathrm{LOH}$ of $9 \mathrm{p}$, resulting in accumulation of mutated $\mathrm{p} 53$ protein in $\operatorname{NSCLC}(54,55)$.

To clarify the relationship of LOH/MSI and carcinogenesis of pulmonary SCC, we compared the early SCC and invasive SCC. The PCR-LOH/MSI analysis showed that chromosomal abnormalities of 1p36 and 9p21 in invasive SCC were as frequent as those in early SCC. There was no statistical difference in expression levels of TAp73 and p16 protein between early SCC and invasive SCC. Brambilla et al suggested that the expression of $\mathrm{p} 16$ protein in invasive NSCLC was lower than that of preinvasive lesions, including mild to severe dysplasia and CIS. They suggested that a loss of p16 protein might precede the acquisition of invasive behavior of NSCLC (56). In our data, no statistical difference was found in expressions of p16 protein between early and invasive SCC. This result suggests that the loss of $\mathrm{p} 16$ protein and LOH/MSI of 9p21 are early events in the carcinogenesis of bronchogenic cancer.

The PDS-2000 AFB system was able to detect abnormal auto-fluorescence even in such precancerous lesions, including squamous dysplasia. Moderate or severe dysplastic lesions that emit abnormal autofluorescence might be treated by bronchoscopical approach such as PDT because, as shown in the present study, these lesions already have chromosomal abnormalities similar to those of early and invasive SCC.

\section{Acknowledgements}

We are grateful to Mr. Masatoshi Sado and Mr. Shizuo Kato at Asahikawa Medical College Hospital Surgical Pathology Service for preparing immunohistochemical staining and thin slice sections for microdissection.

\section{References}

1. Jemal A, Siegel R, Ward E, Murray T, Xu J, Smigal C and Thun MJ: Cancer statistics, 2006. CA Cancer J Clin 56: 106-130, 2006.

2. Goya T, Asamura H, Yoshimura H, et al: Prognosis of 6644 resected non-small cell lung cancers in Japan: a Japanese lung cancer registry study. Lung Cancer 50: 227-234, 2005.

3. Yang P, Allen MS, Aubry MC, et al: Clinical features of 5,628 primary lung cancer patients: experience at Mayo Clinic from 1997 to 2003. Chest 128: 452-462, 2005.

4. Devesa SS, Bray F, Vizcaino AP and Parkin DM: International lung cancer trends by histologic type: male:female differences diminishing and adenocarcinoma rates rising. Int J Cancer 117: 294-299, 2005.

5. American Thoracic Society: Cigarette smoking and health. Am J Respir Crit Care Med 153: 861-865, 1996.

6. Wakai K, Inoue M, Mizoue T, Tanaka K, Tsuji I, Nagata C and Tsugane S: Tobacco smoking and lung cancer risk: an evaluation based on a systematic review of epidemiological evidence among the Japanese population. Jpn J Clin Oncol 36: 309-324, 2006.

7. Cortese DA, Edell ES and Kinsey JH: Photodynamic therapy for early stage squamous cell carcinoma of the lung. Mayo Clin Proc 72: 595-602, 1997. 
8. Furuse K, Fukuoka M, Kato H, et al: A prospective phase II study on photodynamic therapy with photofrin II for centrally located early-stage lung cancer. The Japan Lung Cancer Photodynamic Therapy Study Group. J Clin Oncol 11: 1852-1857, 1993.

9. Lam S: Photodynamic therapy of lung cancer. Semin Oncol 21 (Suppl. 15): S15-S19, 1994

10. Auerbach $\mathrm{O}$ and Garfinkel L: The changing pattern of lung carcinoma. Cancer 68: 1973-1977, 1991

11. Sato M, Saito Y, Usuda K, Takahashi S, Sagawa M and Fujimura S: Occult lung cancer beyond bronchoscopic visibility in sputum-cytology positive patients. Lung Cancer 20: 17-24, 1998.

12. Kennedy TC, Lam S and Hirsch FR: Review of recent advances in fluorescence bronchoscopy in early localization of central airway lung cancer. Oncologist 6: 257-262, 2001.

13. Kusunoki Y, Imamura F, Uda H, Mano M and Horai T: Early detection of lung cancer with laser-induced fluorescence endoscopy and spectrofluorometry. Chest 118: 1776-1782, 2000.

14. Lam S, Kennedy T, Unger M, et al: Localization of bronchial intraepithelial neoplastic lesions by fluorescence bronchoscopy. Chest 113: 696-702, 1998

15. Lam S, MacAulay C, Le Riche JC and Palcic B: Detection and localization of early lung cancer by fluorescence bronchoscopy. Cancer 89 (Suppl. 11): S2468-S2473, 2000

16. O'Neil KM and Johnson BE: Lights flicker on fluorescence bronchoscopy in patients at risk for lung cancer. J Natl Cancer Inst 90: 953-955, 1998.

17. Palcic B, Lam S, Hung J and MacAulay C: Detection and localization of early lung cancer by imaging techniques. Chest 99: 742-743, 1991

18. Chiyo M, Shibuya K, Hoshino H, et al: Effective detection of bronchial preinvasive lesions by a new autofluorescence imaging bronchovideoscope system. Lung Cancer 48: 307-313, 2005.

19. Ohsaki Y, Nishigaki Y, Takeyama K, et al: Visualization of cancer using high sensitive fluorodynamic camera and fiberoptic endoscope. Porphyrins 9: 197-203, 2000.

20. Ohsaki Y, Takeyama K, Nakao S, et al: Detection of photofrin fluorescence from malignant and premalignant lesions in the bronchus using a full-color endscopic fluorescence imaging system: a preliminary report. Diagn Ther Endosc 7: 187-195, 2001.

21. Nakanishi K, Ohsaki Y, Kurihara M, et al: Color autofluorescence from cancer lesions: improved detection of central type lung cancer. Lung Cancer 58: 214-219, 2007

22. Kohno T, Takahashi M, Manda R and Yokota J: Inactivation of the PTEN/MMAC1/TEP1 gene in human lung cancers. Genes Chromosomes Cancer 22: 152-156, 1998.

23. Niklinski J, Niklinska W, Chyczewski L, Becker HD and Pluygers E: Molecular genetic abnormalities in premalignant lung lesions: biological and clinical implications. Eur J Cancer Prev 10: 213-226, 2001

24. Smith ML, Chen IT, Zhan Q, et al: Interaction of the p53regulated protein Gadd 45 with proliferating cell nuclear antigen Science 266: 1376-1380, 1994

25. Zochbauer-Muller S, Gazdar AF and Minna JD: Molecular pathogenesis of lung cancer. Annu Rev Physiol 64: 681-708, 2002.

26. Brennan JA, Boyle JO, Koch WM, et al: Association between cigarette smoking and mutation of the p53 gene in squamouscell carcinoma of the head and neck. N Engl J Med 332: 712-717, 1995.

27. Denissenko MF, Pao A, Tang M and Pfeifer GP: Preferential formation of benzo $[\alpha]$ pyrene adducts at lung cancer mutational hotspots in P53. Science 274: 430-432, 1996.

28. Negrini M, Monaco C, Vorechovsky I, et al: The FHIT gene at 3p14.2 is abnormal in breast carcinomas. Cancer Res 56: 3173-3179, 1996.

29. Nobori T, Miura K, Wu DJ, Lois A, Takabayashi K and Carson DA: Deletions of the cyclin-dependent kinase-4 inhibitor gene in multiple human cancers. Nature 368: 753-756, 1994.

30. Pan H, Califano J, Ponte JF, et al: Loss of heterozygosity patterns provide fingerprints for genetic heterogeneity in multistep cancer progression of tobacco smoke-induced non-small cell lung cancer. Cancer Res 65: 1664-1669, 2005.

31. Yoshino I, Osoegawa A, Yohena T, Kameyama T, Oki E, Oda S and Maehara Y: Loss of heterozygosity $(\mathrm{LOH})$ in non-small cell lung cancer: difference between adenocarcinoma and squamous cell carcinoma. Respir Med 99: 308-312, 2005.

32. Kawakami Y and Ogura S: The outline of the general rule for clinical and pathological record of lung cancer. Nippon Rinsho 58: $999-1004,2000$
33. Cawkwell L, Bell SM, Lewis FA, Dixon MF, Taylor GR and Quirke P: Rapid detection of allele loss in colorectal tumours using microsatellites and fluorescent DNA technology. Br J Cancer 67: 1262-1267, 1993.

34. Erill N, Colomer A, Calvo M, et al: A novel multiplexing, polymerase chain reaction-based assay for the analysis of chromosome 18q status in colorectal cancer. J Mol Diagn 7: 478-485, 2005.

35. Shibata N, Watari J, Fujiya M, Tanno S, Saitoh Y and Kohgo Y: Cell kinetics and genetic instabilities in differentiated type early gastric cancers with different mucin phenotype. Hum Pathol 34: 32-40, 2003.

36. Brown DC and Gatter KC: Ki67 protein: the immaculate deception? Histopathology 40: 2-11, 2002.

37. Allred DC, Harvey JM, Berardo M and Clark GM: Prognostic and predictive factors in breast cancer by immunohistochemical analysis. Mod Pathol 11: 155-168, 1998.

38. Kaghad M, Bonnet H, Yang A, et al: Monoallelically expressed gene related to $\mathrm{p} 53$ at $1 \mathrm{p} 36$, a region frequently deleted in neuroblastoma and other human cancers. Cell 90: 809-819, 1997.

39. Okamoto A, Demetrick DJ, Spillare EA, et al: Mutations and altered expression of p16INK4 in human cancer. Proc Natl Acad Sci USA 91: 11045-11049, 1994.

40. Trink B, Okami K, Wu L, Sriuranpong V, Jen J and Sidransky D: A new human 553 homologue. Nat Med 4: 747-748, 1998.

41. Jost CA, Marin MC and Kaelin WG Jr: p73 is a simian (correction of human) p53-related protein that can induce apoptosis. Nature 389: 191-194, 1997.

42. Ozaki T and Nakagawara A: p73, a sophisticated p53 family member in the cancer world. Cancer Sci 96: 729-737, 2005.

43. Tannock I (ed): The Basic Science of Oncology. 4th edition. McGraw-Hill, New York, 2005.

44. De Laurenzi V, Costanzo A, Barcaroli D, et al: Two new p73 splice variants, gamma and delta, with different transcriptional activity. J Exp Med 188: 1763-1768, 1998.

45. Ueda Y, Hijikata M, Takagi S, Chiba T and Shimotohno K: New p73 variants with altered C-terminal structures have varied transcriptional activities. Oncogene 18: 4993-4998, 1999.

46. Pozniak CD, Radinovic S, Yang A, McKeon F, Kaplan DR and Miller FD: An anti-apoptotic role for the p53 family member, p73, during developmental neuron death. Science 289: 304-306, 2000.

47. Stiewe T, Zimmermann S, Frilling A, Esche H and Putzer BM: Transactivation-deficient DeltaTA-p73 acts as an oncogene. Cancer Res 62: 3598-3602, 2002.

48. Nomoto S, Haruki N, Kondo M, Konishi H, Takahashi T, Takahashi $\mathrm{T}$ and Takahashi $\mathrm{T}$ : Search for mutations and examination of allelic expression imbalance of the p73 gene at 1p36.33 in human lung cancers. Cancer Res 58: 1380-1383, 1998.

49. Sharpless NE, Bardeesy N, Lee KH, et al: Loss of p16Ink4a with retention of p19Arf predisposes mice to tumorigenesis. Nature 413: 86-91, 2001

50. Kishimoto Y, Sugio K, Hung JY, Virmani AK, McIntire DD, Minna JD and Gazdar AF: Allele-specific loss in chromosome $9 \mathrm{p}$ loci in preneoplastic lesions accompanying non-small cell lung cancers. J Natl Cancer Inst 87: 1224-1229, 1995.

51. Kratzke RA, Greatens TM, Rubins JB, Maddaus MA, Niewoehner DE, Niehans GA and Geradts J: Rb and p16INK4a expression in resected non-small cell lung tumors. Cancer Res 56: 3415-3420, 1996

52. Sakaguchi M, Fujii Y, Hirabayashi H, et al: Inversely correlated expression of $\mathrm{p} 16$ and $\mathrm{Rb}$ protein in non-small cell lung cancers: an immunohistochemical study. Int J Cancer 65: 442-445, 1996.

53. Taga S, Osaki T, Ohgami A, et al: Prognostic value of the immunohistochemical detection of p16INK4 expression in nonsmall cell lung carcinoma. Cancer 80: 389-395, 1997.

54. Marsit CJ, Wiencke JK, Nelson HH, Kim DH, Hinds PW, Aldape K and Kelsey KT: Alterations of $9 p$ in squamous cell carcinoma and adenocarcinoma of the lung: association with smoking, TP53, and survival. Cancer Genet Cytogenet 162: 115-121, 2005

55. Zienolddiny S, Ryberg D, Arab MO, Skaug V and Haugen A: Loss of heterozygosity is related to p53 mutations and smoking in lung cancer. Br J Cancer 84: 226-231, 2001.

56. Brambilla E, Gazzeri S, Moro D, Lantuejoul S, Veyrenc S and Brambilla C: Alterations of Rb pathway (Rb-p16INK4-cyclin D1) in preinvasive bronchial lesions. Clin Cancer Res 5: 243-250, 1999. 